\title{
Capitalism Crowding out Fertility
}

\author{
Julia M. Puaschunder \\ The New School, Department of Economics, Schwartz Center for Economic Policy Analysis, NY, USA, \\ Julia.Puaschunder@newschool.edu,http://juliampuaschunder.com/ \\ Columbia University, Graduate School of Arts and Sciences, NY, USA, Julia.Puaschunder@columbia.edu, \\ http://blogs.cuit.columbia.edu/jmp2265/ \\ Princeton University, Julia.Puaschunder@princeton.edu \\ George Washington University, CIBER Center for International Business Education and Research, Duquès Hall, George \\ Washington School of Business, https://blogs.gwu.edu/jpuaschunder/climate-gains-losses/, jpuaschunder@gwu.edu
}

ABSTRACT: In a realm of literature on influence factors on fertility rates; this paper innovatively introduces capitalism being associated with lowered fertility rates. Based on a 180 country strong worldwide data set and cross sectional correlation studies, this paper outlines that hallmark pillars of capitalism are all negatively associated with fertility rates. The 2017 Economic Freedom Index - comprising of input variables such as property rights protection, judicial effectiveness, government integrity, fiscal health, freedom of business, labor, monetary policy, trade, investment, finance, taxation, GDP freedoms as well as FDI inflows - is significantly negatively correlated with fertility rates around the globe. Based on a 139 country strong worldwide dataset on industrialization as measured by the UNIDO in the Industrialization Intensity Index of 2014 and fertility rates, a highly significant negative relation is found between industrialization and fertility rates around the world. Urban areas around the world tend to have higher fertility rates and access to markets within rural communities lowers fertility rates measured by the World Bank Rural Access Index for 64 countries around the world. The inverse relation of economic freedom and fertility was also found for 50 U.S. states based on the 2017 Economic Freedom Index and fertility rates in the United States. The historic examples of communism imploding giving way to free market mechanisms but also an Islamic regime changing towards a Western free market approach captures capitalism to crowd out fertility in a meta-analysis, which also finds higher education levels not being stringently related to fertility rates. Industrialization, globalization and capitalism lead to vanishing populations. Being occupied by production and consumption but also the entertainment of capitalist markets, economic mobility and international trade may distract societies to prosper regarding fertility. Focus on competing in markets may hinder from procreation. Equilibria und markets may have an undocumented negative effect on fertility. Unruled capitalism may lead to a falling rate of fertility, decimating the populace and eventually also the reserve pool of economic agents. The paper concludes with proposals how to use these novel insights as (1) birth control mechanism in those parts of the world, where overpopulation is currently demanding governments to find ways how to lower the fertility rate and (2) means to avert the falling rate of fertility in capitalist societies with a shrinking, aging population. Infusing capitalistic market freedoms in birth control needed territories but also taxing capitalist activities to fund parenthood through direct investment in social benefits and/or via subsidized parenthood to alleviate the tendency of the falling rate of fertility in the eye of capitalism is recommended concurrently, depending on the starting level on the overpopulation-low capitalism versus under-reproduction-high-capitalism spectrum. Revealing the found mechanism has also implications for advocacy to strengthen fertility and the intergenerational glue in light of vanishing populations in the Western world. In addition, the findings have innovative and futuristic prospects in the age of artificial intelligence. Robotics and artificial intelligence slowly taking over human capital labor activities but not being able to reproduce a human DNA is argued to increase the future value of humanness - and with that human fertility - in the artificial age.

KEYWORDS: Artificial intelligence, Business freedom, Capitalism, Capitalism-Fertility Index, Economic Freedom Index, Ethics, Fiscal health, Foreign Direct Investment (FDI), Falling Rate of Fertility, Fertility, Gross Domestic Product (GDP), Government integrity, Index of Economic Freedom, Industrialization, Industrialization Intensity Index, Investment, Judicial effectiveness, Labor freedom, Monetary policy, Overpopulation, Property rights protection, Rural Access Index, Tariffs, Taxation, Trade, Under-reproduction, Urbanization

\section{Introduction}

This paper is structured as follows: The theoretical part starts with an outline of alternative capitalism theories and view of fertility as cause of overpopulation and under-reproduction. The paper then covers the existing literature on a vast array of crowding out factors influencing fertility around the world, featuring hardly any reference to economic variables. It is then innovatively argued that capitalism and access to markets as well as attention to participate in production and consumption curbs people's humane-imbued 
wish for parenthood. A worldwide data sample on capitalism measured by the Index of Economic Freedom is portrayed to be negatively correlated with fertility rates around the world. Tariffs and taxation are associated with higher fertility rates. Based on a 139 country strong worldwide dataset on industrialization as measured by the UNIDO in the Industrialization Intensity Index of 2014 (The World Bank 2014) and fertility rates as reported by the CIA The World Factbook (2018), a highly significantly negative correlation is found between industrialization and fertility rates around the world. Urban areas have lower fertility rates than metropolitan centers and access to markets as measured by the World Bank Rural Access Index is associated with lower fertility rates. This effect also holds for a 50 U.S. states dataset of the 2017 Economic Freedom Index, which reveals economic freedom to be negatively associated with fertility rates in the United States of America. The historical cases of the transition of communist USSR to the more capitalist contemporary Russia as well as the East and West Germany reunification as introduction of East Germany to capital markets; but also the Czech Republic's gaining access to economic markets and the Islamic state Westernization of Iran in the 1990ies are meta-analyzed in order to reveal that access to markets crowds out fertility over time in different parts of the world. In the historic cases, education, on the contrary, is not related to fertility in a stringent way and therefore argued to just be a vehicle to engage in the economic game of producing and consuming; but the actual driving effect being access to capitalist markets. Practical recommendations are targeted at limiting the downsides of international aid creating overpopulation by shifting to opening markets for overpopulated areas and enabling fertility alongside strengthening the intergenerational glue in under-reproduced areas of the world. The paper concludes with policy recommendations how to implement capitalism in overpopulatedlow capitalistic territories and enhance fertility in under-reproduced-high capitalistic countries by curbing capitalism and funding parenthood, which is prospected to become more precious in the digital age.

\section{Theory}

This paper sheds novel light on the complex interactive relationship between capitalism and society. What if the equilibrium has an impact on our social relations? Pricing goods and services guiding our decisions? More concretely, the article argues that deepening economic activities challenge human procreation. The paper thereby takes a heterodox stance to unprecedentedly investigate the relation of access to economic markets and fertility rates.

The effect of education on fertility rates is well-documented in the economics, international development and governance literature (Cochrane 2010). Once female obtain higher education in a society, they are less likely to have children and tend to have less children. The more educated a population, the more the fertility rate declines. This paper revises this idea by reporting a crowding out effect of capitalism on fertility. Education may only be a part of the picture and the actual driving effect stems from the wish to compete in economic markets better through being more educated. Market economies thereby bleed into market societies, in which individuals forget to procreate in the eye of anticipating future market point equilibrating situations, in which their labor power becomes competitively commodified and their resumes need to feature distinct credentials, which to acquire blocks them from reproduction. Individual's attention being occupied by consumption and production in the wake of industrialization, may also imply unexpected socio-economic developments. Markets may leave a mark on society. Pricing of human labor may erode human procreation.

Since the post-World War period, the world globalized. International economic activities now involve a larger number of countries and sectors than at any time in history. Capitalism reaches deeper into every human life than ever before (Held \& McGrew 2007). Globalization led to unknown systemic economic risks on a global scale (Centeno et al. 2013; Okamoto 2009; Urry 2012). In the light of growing anti-globalization tendencies, the demand for an in-depth understanding of how markets influence society gained unprecedented momentum. New economic thinking widens the interdisciplinary lens to study emergent risks of how the spread of economic markets around the world may influence the societal compound. The shadow of economic freedom may echo in society. Applying emergent risk theory onto economic outcomes on society is an innovative way to foresee the potentials of capitalism but also prevent the negative outcomes of an industrialized world (Centeno et al. 2013; Held \& McGrew 2007). 


\section{Research question}

In exceeding orthodox economics' insights and traditional public policy attempts to curb societal risks, a heterodox economics approach may capture the impact of economic markets on fertility as real-world emergent risk prevention strategy. Economic indicators of product wages, international trade, economic competition, output-capital ratio, and post-tax profits have been studied extensively to derive conclusions about societal prosperity. In the economics, international development and public policy literature, the negative impact of education on fertility is widely discussed. The relation of economic correlates on fertility, however, is hardly addressed. The following article therefore sets out to relate access to economic markets to the fertility rates around the world, in the U.S. as well as in historic economic transition cases of socialist-communism and Islamic countries in order to derive recommendations on what the right dose of capitalism is around an overcrowded planet featuring also under-reproduced societies.

\section{Method}

Based on a 180 country strong worldwide data set and cross sectional correlation studies as well as U.S. data and a historic case study meta-analysis, this paper outlines that hallmark pillars of capitalism and industrialization are negatively correlated with fertility rates. Taxation and tariffs, on the other contrary, are associated with higher fertility rates. A worldwide dataset on industrialization as measured by the UNIDO in the Industrialization Intensity Index and fertility rates, consolidate a highly significant negative relation between industrialization and fertility rates around the world. Urban areas around the world tend to have higher fertility rates than metropolitan centers, while access to markets within rural communities lowers fertility rates. Education may therefore just be a vehicle to engage in the economic game of producing and consuming. Selling us the idea that education drives out fertility in a society may thus just sugarcoat the fact that industrialization, globalization and capitalism lead to vanishing populations. Being occupied by production and consumption but also entertainment, mobility and internationally-traded products and services alongside online access to markets may distract societies to prosper regarding fertility. In the Marxian tradition (1867/1995), unruled capitalism may therefore lead to a falling rate of fertility, decimating the populace and eventually also the reserve pool of economic agents.

\section{Discussion}

In the discussion, this paper pays tribute to the positive and negative externalities of capitalism on fertility rates depending on where populations start from regarding their fertility rates on an overpopulation and under-reproduction spectrum. Outlining the found mechanism has implications for advocacy to either use economic markets to control overpopulation in less economically enclosed market areas or strengthen fertility and the intergenerational glue in Western world vanishing populations living in highly developed market economies. Having found a way how to naturally curb overpopulation, negative coercion or biased birth phenomena of overpopulated world territories may be evaded. For Western world market economies that report a decline of the population, the paper provides recommendations how to alleviate the falling rate of fertility tendency in the eye of capitalism. Capitalism's declining need for labor may either be used to curb an overpopulated planet in those territories with exploding populations; or can lead to a hardly described societal downfall in well-established market economies, where capitalism is eroding itself given a shrinking pool of economic agents in advanced economies.

\section{Conclusion}

The paper concludes with proposals how to use market freedom to curb overpopulation in over-fertile countries but also how to avert the falling rate of fertility in vanishing societies of Western world market economic territories through taxing capitalist activities to fund parenthood by tax revenues, direct investment and/or subsidies and social benefits. In its entirety, the following paper also holds valuable contributions to sustainability pledges in the eye of an overpopulated planet with scarce resources as it offers concrete advice how to curb implicit industrialization failures' socio-economic consequences down the road and potentially-disastrous outcomes of globalization over time. 
The findings also have innovative and futuristic implications in the age of artificial intelligence. Shedding light on these insufficiently-described shadows of free markets of the world economy in the age of globalization is of highest importance regarding the future rise of digital innovations. With the prospect of automated control and artificial intelligence taking over manual, repetitive tasks, humanness - hence activities that are innate and unique for human beings - is likely to become more precious. Robotics and artificial intelligence slowly taking over human capital labor activities but not being able to reproduce a DNA is argued to increase the value of humanness - and with that human fertility - in the future artificial intelligence age to come. Outlining the positive potential and negative impacts of industrialization, globalization and capitalism on fertility rates holds the key to argue for human reproduction to be considered as a means of production that is unique to human beings and should become directly remunerated in the digital age.

\section{References}

Centeno, M.A., Cinlar, E., Cloud, D., Creager, A.N., DiMaggio, P.J., Dixit, A.K., Elga, A.N., Felten, E.W., James, H., Katz, St.N., Keohane, R.O., Leonard, Th.C., Massey, W.A., Mian, A.R., Mian, Z., Oppenheimer, M., Shafir, E. \& Shapiro, J.N. 2013. Global systemic risk. Unpublished manuscript for research community. Princeton Institute for International and Regional Studies, Princeton University, New Jersey, April 2013.

Cochrane, S.H. 2010. Fertility and education: What do we really know. Washington, D.C.: World Bank. http://documents.worldbank.org/curated/en/550621468765918708/Fertility-and-education-what-do-we-really-know.

Held, D. \& McGrew, A.G. 2007. A new world economic order? Global markets and state power: Beyond globalization/antiglobalization: Beyond the great divide. New York, NY: Polity.

Marx, K. 1867/1995. Capital: A critique of political economy. Moscow, RU: Progress.

Okamoto, K.S. 2009. After the bailout: Regulating systemic moral hazard. UCLA Law Review, 57, 1, 183-236.

The World Bank. 2014. Industrialization Intensity Index, Data Set: UNIDO - Competitive Industrial Performance Index. https://tcdata360.worldbank.org/indicators/mva.ind.int?country=USA\&indicator=3793\&countries=BRA\&viz=line_chart\&y ears $=1990,2014$.

The World Factbook. 2018. Washington, DC: Central Intelligence Agency, 2018. Continually updated. https://www.cia.gov/library/publications/the-world-factbook/.

Urry, J. 2012. Complex systems and crises of energy. Working paper. Lancaster, UK: University of Lancaster. 